професійного самовдосконалення, високої результативності, комунікабельності, самоорганізації, самоосвіченості і забезпечує глибину та повноту розвитку наукових, аналітичних, творчих здібностей майбутніх учителів гуманітарних дисциплін у межах єдиного освітнього простору.

\title{
Література
}

1. Ардеев А. Х. Концепция информационно-образовательной среды в системе высшего профессионального образования/ А. Х. Ардеев// Молодежь и наука III тысячелетия: Материалы Краевой научной Internet-конференции студентов, молодых ученых и специалистов. - Ставрополь : Изд-во Ставропольский госуд. ун-т, 2003. - С. 178-180. 2. Башмаков М. И. Понятие информационной среды процесса обучения / М. И. Башмаков, С. И. Позняков, Н. А. Резник // Школьные технологии. 2000. - № 2. - С. 153-182. 3. Башмаков М. И. Процесс обучения в информационной среде / М. И. Башмаков, С. Н. Поздняков, Н. А. Резник // Школьные технологии. 2000. - № 6. - С. 133-159. 4. Выготский Л. С. Педагогическая психология / Л. С. Выготский ; под ред. В. В. Давыдова. - М : Педагогика, 1991. - 82 с. 5. Глоссарий по информационному обществу. [Электронный ресурс].- Режим доступу : http://www.iis.ru/glosary/infenviro ment.ru.html. 6. Поляков А. А. Информационнообразовательная среда открытого образования / А. А. Поляков // Народное образование. - 2000. - № 8. - С. 43-45. 7. Путилов Г. П. Концепция построения информационно-образовательной среды технического вуза / Г. П. Путилов.-М. : МГИЭМ, 1999. - 28 с. 8. Русский портал открытого образования : обучение, опыт, организация ; отв. ред. В. И. Солдаткин. - М. : МГИУ, 2003. - 508 с. 9. Толковый словарь по основам информационной деятельности; под ред. Н. Н. Ермошенко. - К., 1996. -252 c.

УДК $371.15+378.124+378.147+372.461$

Ірина Княжева

\section{НОРМАТИВНИЙ КУРС «МЕТОДИКА ВИКЛАДАННЯ ПЕДАГОГІЧНИХ ДИСЦИПЛІН У ВИЩИХ НАВЧАЛЬНИХ ЗАКЛАДАХ» У ФОРМУВАННІ МЕТОДИЧНОЇ КУЛЬТУРИ МАЙБУТНІХ ВИКЛАДАЧІВ}

Княжева I. А. Нормативний курс «Методика викладання педагогічних дисциплін у вищих навчальних закладах» у формуванні методичної культури майбутніх викладачів.

У статті розглянуто зміст авторської програми курсу «Методика викладання педагогічних дисциплін у вищих навчальних закладах», що слугує засобом формування методичної культури майбутніх викладачів. Автор конкретизує зміст поняття «методична культура майбутніх викладачів».

Ключові слова: методична культура, майбутні викладачі, методика викладання, педагогічні дисципліни, вищий навчальний заклад.

Княжева И. А. Нормативный курс «Методика преподавания педагогических дисциплин в высших учебных заведениях» в формировании методической культуры будущих преподавателей.

В статье рассмотрено содержание авторской программы курса «Методика преподавания педагогических дисциплин в высших учебных заведениях», служащей средством формирования методической культуры будущих преподавателей. Автор конкретизирует содержание понятия «методическая культура будущих преподавателей». 
Ключевые слова: методическая культура, будущие преподаватели, методика преподавания, педагогические дисциплины, высшее учебное заведение.

Knyazheva I. A. Normative course «Method of teaching of pedagogical disciplines in higher educational establishments» in forming of methodical culture of future teachers.

In the article there is considered the maintenance of the author program of course «Method of teaching of pedagogical disciplines in higher educational establishments», used by the mean of forming of methodical culture of future teachers. An author specifies maintenance of concept «Methodical culture of future teachers».

Key words: methodical culture, future teachers, teaching method, pedagogical disciplines, higher educational establishment.

Сучасний етап розвитку нашого суспільства пов'язаний iз необхідністю підвищення якості освітньої діяльності вищих навчальних закладів i, як наслідок, забезпечення можливості здобуття в них високого рівня вищої освіти. Ефективне розв'язання цього завдання значною мірою залежить від якості кадрового забезпечення вищих навчальних закладів, від молодих спеціалістів - сьогоднішніх магістрантів, які ввіллються до викладацьких лав. Активний пошук можливостей підвищення ефективності професійної підготовки майбутніх викладачів вищої школи, важливим показником якої $\epsilon$ рівень розвитку їхньої методичної культури, актуалізується об'єктивно існуючою невідповідністю між суспільними вимогами й реальним рівнем такої підготовки.

Розкриттю особливостей педагогічної діяльності і шляхів професійного становлення викладачів вищих навчальних закладів присвячені наукові дослідження А. Барабанщикова, С. Вітвицької, О. Гури, 3. Ссаревої, I. Ісаєва, Н. Кузьміної, В. Сластьоніна, Ю. Фокіна та ін. Досліджується стратегія і тактика підготовки педагогічних кадрів в умовах університетської освіти (А. Алексюк, В. Бондар, О. Глузман, Ф. Гоноболін, Л. Коваль, Л. Маркова, О. Мороз, Л. Нечепоренко, Ю. Поваренков та ін.). Аналізується процес професійного становлення педагога як результат його самовизначення в культурі (Г. Богомолова, І. Бех, Е. Бондаревська, М. Букач, В. Гриньова, I. Колесникова, Г. Михалкін, I. Пальшкова, . Рудницька, Н. Шеховська, І. Якиманська та ін.). Натомість вивчення наукової літератури з проблеми формування методичної культури переконливо засвідчує, що незважаючи на суттєвий доробок дослідження методичної сфери у професійно-педагогічній підготовці (О. Абдуліна, К. Абраменко, І. Ковальова, Н. Никитенко, Г. Падалка, С. Пятаєва, Л. Спірін, Т. Сясіна, Л. Таланова, С. Татарінцева, Г. Тарасенко, О. Тімакіна, Г. Філіпчук, М. Шалунова та ін.), зокрема, педагогів певного фаху, учителів окремих предметів

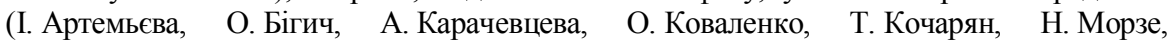
О. Соколова, В. Шарко та ін.), питання, пов'язані із формуванням методичної культури майбутніх викладачів вищої школи, донині залишаються малодослідженими.

Метою статті є з'ясування особливостей курсу «Методика викладання педагогічних дисциплін у вищих навчальних закладах» та визначення його можливостей щодо формування методичної культури майбутніх викладачів в умовах магістратури.

Методичну культуру майбутнього викладача розуміємо як системне динамічне особистісне утворення, що виявляється в його здатності до рефлексивного осмислення, привласнення, відтворення i продукування ціннісних сенсів та змісту методик i технологій викладацької діяльності. 
Нагальна потреба пошуку резервів формування i розвитку методичної культуримайбутніх викладачів педагогічних дисциплін як висококомпетентних i різнобічно освічених кваліфікованих фахівців своєї справи, спроможних ініціативно, самостійно працювати, творчо й нестандартно мислити, оперативно приймати рішення, призвела до розуміння необхідності організації педагогічного керівництва цим процесом.

Формування розуміємо як процес становлення особистості під дією зовнішніх і внутрішніх, цілеспрямованих та стихійних чинників [1; 2]. Таке розуміння цього процесу спрямовує на переорієнтацію змісту професійної підготовки майбутніх викладачів з традиційного знаннєвого підходу на практико й особистісно зорієнтований, що передбачає створення необхідних умов для їхнього поступового професійного зростання на засадах самоорганізації і саморозвитку. Важливе місце в цьому процесі належить розробленому автором курсу «Методика викладання педагогічних дисциплін у ВНЗ», що є нормативною навчальною дисципліною професійно орієнтованого циклу. Метою курсу є теоретична і практична підготовка фахівців напряму «Педагогічна освіта» професійного спрямування 8.010101 «Дошкільна освіта» спеціальності «Викладач дошкільної педагогіки і психології» освітньо-кваліфікаційного рівня «Магістр» до викладання педагогічних дисциплін у вищих навчальних закладах.

Провідним завданням курсу $\epsilon$ формування i розвиток методичної культури майбутніх викладачів педагогічних дисциплін. Структуру методичної культури майбутнього викладача вищої школи зумовлює єдність чотирьох компонентів: когнітивного (знаю, уявляю, розумію), діяльнісно-організаційного (дію, реалізую, привласнюю знання, організовую діяльність), мотиваційно-ціннісного (хочу, прагну, цікавлюсь, розумію значущість), рефлексивно-оцінного (дію, реалізую, організовую себе й інших, творю, вмію). Детальний аналіз кожного 3 компонентів методичної культури дозволив провести дослідження їх формування у процесі вивчення навчальної дисципліни «Методика викладання педагогічних дисциплін у ВНЗ».

У процесі вивчення курсу здійснюється усвідомлення майбутніми викладачами особливостей процесу навчання у ВНЗ та його організації; засвоєння методології та сучасних методик викладання педагогічних дисциплін у вищих педагогічних навчальних закладах, змісту і форм організації самостійної пізнавальної діяльності студентів; опанування основних документів, що регламентують діяльність викладача ВНЗ і перспективи розвитку вищої педагогічної освіти в Україні, а також пов' язаних із безпосередньою роботою викладача (базовий навчальний план, навчальна програма, робоча навчальна програма дисципліни); набуття магістрантами практичного досвіду використання теоретичних знань 3 методики викладання педагогічних дисциплін (вміння структурувати зміст навчального матеріалу за його логікою, визначати знання й уміння, що мають засвоюватися студентами у ВНЗ; добирати форми і методи навчання та виховання, залежні від мети навчальної діяльності й індивідуальних здібностей студентів як суб'єктів навчання і виховання; аналізувати навчальні заняття і визначати ïх ефективність тощо); формування і розвиток у магістрантів навичок творчого i критичного мислення, оцінної діяльності, планування й аналізу ефективності аудиторної та позааудиторної роботи зі студентами у процесі викладання педагогічних дисциплін, виховної і науково-методичної роботи; уміння розшукувати, систематизувати, зберігати й узагальнювати необхідну інформацію за змістом навчального курсу; формування в майбутніх викладачів педагогічних дисциплін відповідального ставлення до професійної діяльності, навичок професійного саморозвитку і самовдосконалення. Означені завдання охоплюють усі компоненти методичної культури майбутніх викладачів. 
За навчальним планом на вивчення нормативної навчальної дисципліни «Методика викладання педагогічних дисциплін у ВНЗ» відведено 180 годин (5,5 кредитів), з них згідно 3 розробленою нами програмою: 41 година на лекційні заняття, 9- на семінарські, 21 - на практичні, 12 - на навчальний проект і 97 - на самостійну й індивідуальну роботу майбутніх викладачів. Це відповідає сучасним вимогам щодо співвідношення кількості аудиторної і самостійної роботи. Тижневе навантаження магістрантів 3 цього курсу складає чотири години.

Розроблена автором навчальна програма курсу передбачає чотири змістових модулі: «Зміст і нормативно-правова база викладання дисциплін педагогічного циклу у ВНЗ», «Організація навчального процесу в педагогічному вищому навчальному закладі», «Методика проектування і проведення різних видів навчальних занять», «Становлення і розвиток методичної культури майбутніх викладачів педагогічних дисциплін». Розглянемо більш детально зміст означених модулів. Перший модуль передбачає вивчення трьох тем. Під час вивчення першої теми «Місце курсу «МВПД у ВНЗ» у структурі професійної підготовки викладача педагогічних дисциплін вищої школи» розглядається поняття про методику викладання педагогічних дисциплін, місце і функції курсу «Методика викладання педагогічних дисциплін у вищих навчальних закладах» у підготовці магістрів зі спеціальності «Дошкільна освіта» освітньокваліфікаційного рівня «Магістр» до професійної діяльності викладача ВН3; предмет, мета і завдання курсу «МВПД у ВНЗ»; педагогічна наука і педагогічна практика як джерело змісту означеного навчального курсу; зв'язок методики викладання педагогічних дисциплін з іншими науками.

Під час роботи над другою темою - «Нормативна база 3 організації процесу навчання в педагогічному ВНЗ»- майбутні викладачі опановують закони України і нормативні акти щодо організації системи вищої професійної педагогічної освіти; особливості діяльності вищої школи в сучасних умовах; міжнародні вимоги щодо вищої освіти і перспективи створення єдиного європейського простору вищої освіти («Всесвітня декларація про вищу освіту для XXI століття: підходи і практичні заходи», Болонська декларація, «Велика Хартія Університетів»). Визначають положення Національної доктрини розвитку освіти України у XXI столітті щодо вимог i вдосконалення професійно-педагогічної підготовки майбутніх фахівців у вищій школі, «Положення про організацію навчального процесу у вищих навчальних закладах» щодо організаційних основ роботи педагогічного ВНЗ, систему стандартів вищої освіти України. Розглядається проблема запровадження освітніх стандартів і створення на їх основі освітньо-професійних програм і структурно-логічної схеми підготовки, навчальний план та характеристика його обов'язкових складників; навчальна програма дисципліни, сучасні вимоги щодо ії змісту.

Третя тема першого модуля «Цикл педагогічних дисциплін та його навчальнометодичне забезпечення» передбачає здійснення загальної характеристики навчальних дисциплін, що входять до циклу фахових педагогічних дисциплін, порівняльну характеристику структури і змісту циклу педагогічних дисциплін у ВН3 I-II та III-IV рівнів акредитації за спеціальністю «Дошкільна освіта»; окреслення сучасних вимоги щодо визначення змісту курсу педагогічних дисциплін, з'ясування мети викладання навчального предметf; змісту і завдань курсів: «Вступ до спеціальності», «Загальна педагогіка», «Дошкільна педагогіка», «Історія дошкільної педагогіки», їх взаємозв’язок та взаємозумовленість, місце в системі підготовки педагогічних кадрів спеціальності «Дошкільна освіта». Визначення логіки побудови навчального курсу циклу педагогічних дисциплін (методологія, діалектика побудови, джерела розвитку) i 3’ ясування можливих варіантів впорядкування змісту педагогічних дисциплін у ВН3 1-2 
та 3-4 рівнів акредитації (відповідно до навчальних планів і програм), використання інваріантного і варіативного підходу у визначенні змісту педагогічних дисциплін, використання таксономії навчальних завдань для аналізу змісту педагогічної дисципліни; аналіз сучасних підручників i навчальних посібників 3 педагогічних дисциплін; робочої навчальної програми дисципліни, іiі структурних складників; традиційних і модульних моделей робочих навчальних програм, технології розроблення робочої навчальної програми курсу сприяють формуванню методичної культури майбутніх викладачів.

Другий змістовий модуль охоплює п'ять тем. Так, у процесі опанування теми «Форми організації навчально-пізнавальної діяльності студентів у процесі вивчення педагогічних дисциплін» магістранти актуалізують поняття про організаційні форми навчання у ВНЗ, простежують зв'язок між моделлю професійної підготовки й організаційними формами, історію виникнення i розвитку організаційних форм навчання дорослих, здійснюють характеристику традиційних та інноваційних організаційних форм. У процесі вивчення теми «Методика організації самостійної роботи студентів у процесі вивчення педагогічних дисциплін» з'ясовується: сутність, значення і функції самостійної роботи студентів педагогічного ВНЗ; ознаки самостійної роботи; дається характеристика основних типів, видів і форм самостійної роботи, інноваційних i традиційних форм та видів завдань для самостійної роботи; визначаються рівні самостійності, принципи конструювання завдань, методика розроблення завдань для самостійної роботи, вимоги до організації самостійної роботи студентів у процесі вивчення педагогічних дисциплін; методика керівництва самостійною діяльністю студентів, конструювання методичних рекомендацій для студентів щодо організації самостійної роботи; можливості оцінювання результатів самостійної діяльності студентів. Тема «Методика проектування змісту і керівництва педагогічною практикою студентів спеціальності «Дошкільна освіта» передбачає визначення мети педагогічної практики, іiі форм, видів, ознайомлення з наскрізними програмами педагогічної практики студентів у ВН3 1-2 і 3-4 рівнів акредитації, робочою програмою практики, здійснення іiі аналізу i визначення методики проектування. Під час вивчення теми «Методи і засоби викладання педагогічних дисциплін» актуалізуються уявлення магістрантів щодо методів, методики і технологій навчання, класифікацію методів навчання і критерії їх вибору; опановується методика активного навчання і використання засобів навчання у викладанні педагогічних дисциплін, визначаються умови їх ефективного застосування. Тема «Інноваційні підходи до організації навчання у ВНЗ» передбачає розгляд проблеми організації навчального процесу у вищому педагогічному навчальному закладі, історії і сучасності у впровадженні інноваційних технологій навчання, можливостей розвитку технологій навчання, оцінки їх результативності; характеристику стилів і видів навчання, принципів організації взаємодії викладачів і студентів, зміну функціонально-рольових уявлень про викладацьку діяльність. Робиться висновок про варіативність педагогічної позиції і ролей викладача як модератора, фасілітатора, методолога, тьютора, коуча, ігротехніка.

Третій змістовий модуль охоплює чотири теми, робота в межах яких сприяє опануванню методики проектування і проведення лекцій, семінарських, практичних та лабораторних занять 3 педагогічних дисциплін, методику проектування і проведення контролю навчальних досягнень студентів 3 педагогічних дисциплін, які спрямовані на формування діяльнісно-організаційного i рефлексивно-оцінного компонентів методичної культури майбутніх викладачів. Так, у межах першої теми цього модуля з'ясовується історія виникнення, сутнісна характеристика і функції лекції в контексті 
сучасної вищої освіти; визначаються структурні і функціональні особливості видів і основні напрями модифікації лекції, логіка i технологія іiі проектування, види викладання, правила мовного оформлення навчальної інформації; методика підготовки конспекту лекції, види конспектів, фази організації навчального простору на лекції; методика проведення різних видів лекцій; визначаються критерії оцінки якості лекції. Друга тема присвячена здійсненню сутнісної характеристики і функцій семінарських занять, їх місця в навчальному процесі сучасного педагогічного ВНЗ; проводиться порівняльна характеристика типів семінарських занять, визначається їх структура та функції викладача і студентів; вимоги до проведення семінарів; методика проведення різних типів семінарських занять і критерії оцінки їхньої якості. У ході роботи в межах третьої теми цього модуля 3'ясовується мета і функції лабораторних та практичних занять у викладанні педагогічних дисциплін, їх специфіка, сучасні підходи до організації; методика використання інтерактивних методів і технологій навчання; критерії оцінки якості практичних і лабораторних занять; алгоритм підготовки викладача до практичного i лабораторного заняття, способи аналізу і рефлексії підготовки та проведення практичного i лабораторного заняття 3 педагогічних дисциплін. Остання тема третього змістового модуля присвячена розкриттю поняття «педагогічний моніторинг» і «контроль якості»; функцій контролю в системі організації навчальної діяльності студентів; вимоги до проведення контролю, його видів; характеристиці i методиці проведення поточного, тематичного i підсумкового контролю; форм самоконтролю студентів; критеріїв та систем оцінювання навчальних досягнень студентів.

Четвертий змістовий модуль «Становлення i розвиток методичної культури майбутніх викладачів педагогічних дисциплін» охоплює такі теми «Вимоги щодо підготовки майбутніх викладачів для педагогічних ВНЗ», «Методична культура в соціальному й особистісному вимірах» $\mathrm{i}$ «Методичний складник професійної діяльності викладача педагогічних дисциплін як джерело розвитку його методичної культури». Окреслимо коло проблем, яким присвячено цей модуль: теоретична і практична підготовка майбутніх педагогів спеціальності «Дошкільна освіта»; основні напрями діяльності i функції викладача (освітня, виховна, методична, організаторська, дослідницька); поняття про педагогічну культуру i педагогічну компетентність викладачів ВНЗ; методична культура як важливий показник якості підготовки викладача педагогічних дисциплін до професійно-педагогічної діяльності; сутність методичної культури як соціокультурного феномену; методична культура майбутнього викладача педагогічних дисциплін: iï особливості, структура і рівні розвитку; перспективи розвитку методичної культури майбутніх викладачів педагогічних дисциплін в умовах магістратури; методичний складник та його специфіка в роботі викладача педагогічних дисциплін ВНЗ; сутність, мета, завдання і функції методичної діяльності викладача педагогічних дисциплін сучасного ВН3; напрями i зміст методичної діяльності викладача педагогічних дисциплін; форми здійснення методичної діяльності; планування як основа методичного забезпечення освітнього процесу; результати методичної діяльності; вимоги до методичних розробок; оформлення продуктів методичної діяльності викладача (доповідь, стаття, портфоліо педагогічних досягнень, навчально-методичне забезпечення педагогічних дисциплін тощо) i способи їх створення; критерії аналізу якості різних видів методичної продукції; розвиток методичної культури викладача ВНЗ у просторі його професійної діяльності.

Упровадження вказаних тем, кожна 3 яких наскрізно проходить через усі форми аудиторних занять і самостійну та індивідуальну роботу магістрантів, відображено у змісті викладацької практики магістрантів, потребувало добір і розроблення відповідних до 
змісту активних методів його опанування та передбачало розробку відповідних дидактичних засобів: програм вивчення тем, методичних рекомендацій щодо їх опанування, навчального посібника, програмних засобів, завдань для самостійної роботи студентів, програми педагогічної (викладацької) практики у вищих навчальних закладах.

Експериментально доведено доцільність упровадження в навчальний процес курсу «Методика викладання педагогічних дисциплін у ВНЗ» за авторською програмою, зміст якої затверджено методичною комісією i вченою радою Державного закладу «Південноукраїнський національний педагогічний університет імені К. Ушинського», та iï позитивний вплив на формування методичної культури майбутніх викладачів.

Отже, інтеграція змісту нормативного курсу «Методика викладання педагогічних дисциплін у вищих навчальних закладах», авторської програми, дидактичних засобів, форм і методів його реалізації слугує розв'язанню проблеми підвищення якості професійно-педагогічної підготовки майбутніх викладачів в умовах магістратури, важливим показником якої $є$ формування і розвиток їхньої методичної культури.

Перспективу подальших наукових розвідок убачаємо в розробленні цілісної технології розвитку методичної культури майбутніх викладачів педагогічних дисциплін в умовах магістратури.

\section{Література}

1. Подласый И. П. Педагогика. Новый курс : [учебник для студ. пед. вузов] : В 2 кн. / И. П. Подласый. - М. : Гуманит. изд. центр. ВЛАДОС. - 2000. - Кн. 1 : Общие основы. Процесс обучения. - 576 с. 2. Сластенин В. А. О проектировании содержания высшего педагогического образования / В. А. Сластенин // Преподаватель. - 1999. № 5. - С. 3-9.

\section{ЗДОРОВ' ЯЗБЕРІГАЛЬНА КОМПЕТЕНТНІСТЬ МАЙБУТНІХ УЧИТЕЛІВ ПОЧАТКОВИХ КЛАСІВ: ПОНЯТТЯ І СТРУКТУРА}

Ландо О. А. Здоров'язберігальна компетентність майбутніх учителів початкових класів: поняття і структура.

Статтю присвячено проблемі здоров'язберігальної компетентності майбутніх учителів початкових класів. Розкрито поняття i структуру здоров'язберігальної компетентності майбутніх учителів початкових класів, а також необхідність усвідомленого ставлення майбутніх учителів до здоров'я та здорового способу життя.

Ключові слова: компетенція, компетентність, здоров'язбереження.

Ландо О. А. Здоровьесберегающая компетентность будущих учителей начальных классов: понятие и структура.

Статья посвящена проблеме здоровьесберегающей компетентности будущих учителей начального образования. Раскрыты понятие и структура здоровьесберегающей компетентности будущих учителей начального образования, а также необходимость осознанного отношения будущих учителей к здоровью и здоровому образу жизни.

Ключевые слова: компетенция, компетентность, здоровьесбережение.

Lando O. A. The healthcare competence of primary school teachers: the notion and structure.

The article is devoted to the problem of healthcare competence of primary school teachers. The notion and structure of healthcare competence of future primary school teachers 